\title{
Impact of Catholic Monastery Church Building on Cistercian Monastery Formation in Livonia and the State of the Teutonic Order during 13th and 14th Century
}

\author{
Silvija Ozola, Riga Technical University
}

\begin{abstract}
Convinced Christians, in order to sacrifice themselves to God, became monks. In Italy and other remote places or at important traffic roads, building of monasteries for religious, educating and social needs was started, services and schools were organized, accommodation for travellers provided. Without applying concrete, a homogeneous planning monumental monastery churches with massive walls, restrained décor, wooden ceilings, semi cylindrical ridge or altarpiece (Latin: presbyterium) at the building eastern end were built. In churches, rooms with small windows were dark and enigmatic. Due to the impact of relics, the dead and martyrs' commemoration cult and ideology, basilicas had more extended planning: at the nave's eastern end a podium for the altar was made. In walls a semicircle planning chancel's niche or apse and windows were built. In order to organize ritual processions, chapels for extra altars arranged in the cross-nave or transept. The entrance into the apse joined both side-naves and surrounded by the chancel. The building's plan obtained a shape of a Latin cross. Symbolism was not the determinant factor, but rather the functionality of room. The transept, which earlier had been considered as underlying, became more important than the nave, which since the $5^{\text {th }}$ century searches for fireproof cover formation and new planning and vault solutions were necessary.

In the early $9^{\text {th }}$ century economic boom promoted foundation of markets and commodity exchange, building of roads, pilgrims' movement, rebirth of cities and culture. Local masters built churches and monasteries, creating compositions of manifold construction forms. Bishops' cathedrals had a small chancel, but in abbey churches, extending aisles, the chancel obtained unusual sizes. In large abbeys even two aisles, separated with the central arcade, and side apses were made. In the $10^{\text {th }}$ century, in basilicas with the planning similar to the Latin cross buildings with three apse eastern-end for services place were carefully made. In the western façade, on each side of the entrance a tower was built. In Western Europe big, rich abbeys became important in economics, religion and secular politics. Applying their authority and impact on society, during the course of a very complex evolution, they created a new abbey church type.

Monasteries were subordinated to the bishop, but not so often to the Roman Pope. Abbeys not subordinated to the bishop created their separate (Latin: abbas nullius) or territorial abbeys (Latin: abbas territorialis). The first (800-814) Emperor (Latin: Imperatores Romani Sacri, German: Römisch-deutscher Kaiser) of the Holy Rome Charles the Great (French: Charlemagne, German: Karl der Große) with the help of monks' community lifestyle regulations Regula Benedicti (around 540), formulated by St. Benedict of Nursia, created abbeys for the Holy Roman Empire's administrative system. In the lands of the Balts, for the implementation of the cross-war policy and for deployment of military units, monks-knights built fortress-like financially and economically independent Cistercian monasteries where chapels were installed. The Cistercian sacral buildings were modest.
\end{abstract}

Keywords: Benedictines, Cistercians, Livonia, monastery church, State of the Teutonic Order

Introduction

In Italian north-west region Lombardy, Irish monks built a church on ruins of an ancient temple and founded the important Farfa Abbey (Italian: Abbazia di Santa Maria di Farfa, Latin: Abbatia Farfensis; round 681). In Italy, Benedictine traditions revived. In summer 742, in German lands Saint Boniface (Latin: Bonifatius; around 675?-754) encouraged Saint Sturm (around 705-779) to found a great monastery and church. In January 744, Saint Sturm chose a plot of land for the monastery in an uninhabited place by the River Fulda and after receiving the permit for building he went to the famous St. Benedict's monastery in Monte Cassino (Italian: Abaazia Montecassino; 529) to obtain an inspiration for creation of magnificent abbey. On March 12, 744 Saint Sturm and Saint Boniface founded the monastery of Fulda (Latin: Abbatia Fuldensis, Dioecesis Fuldensis, German: Fürstabtei Fulda, Hochstift Fulda, Kloster Fulda) (Fig. 1.), which adopted the Regula Benedicti. The first abbot (744-779) Saint Sturm, who since November 4, 751 was under the Roman Pope's direct subjugation, took care of monastery's development and created an autonomous spiritual territory of the Princely Abbey of Fulda (German:Reichsabtei $F u l d a$ ). During the $8^{\text {th }}-9^{\text {th }}$ century, the Princely Abbey of Fulda became a prominent Christians' education and culture centre. The third abbot of Fulda 


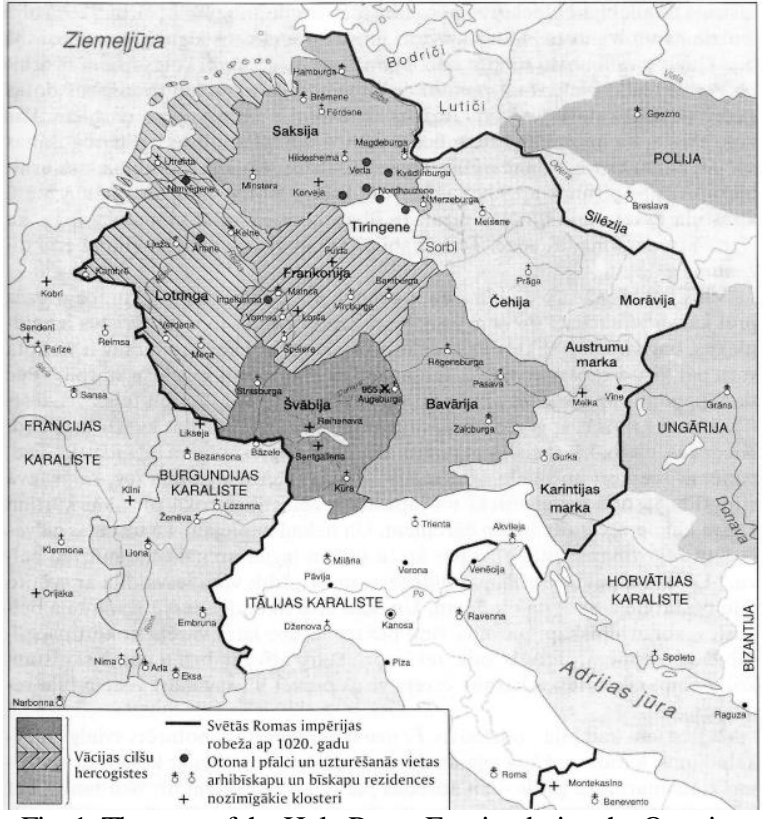

Fig. 1. The map of the Holy Rome Empire during the Ottonian dinasty regin from 911 to $1024[8,93]$

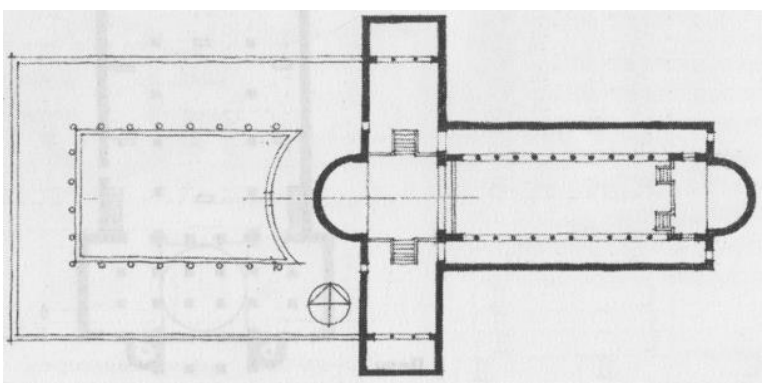

Fig. 2. The plan of the basilica of Fulda monastery $[19,311]$

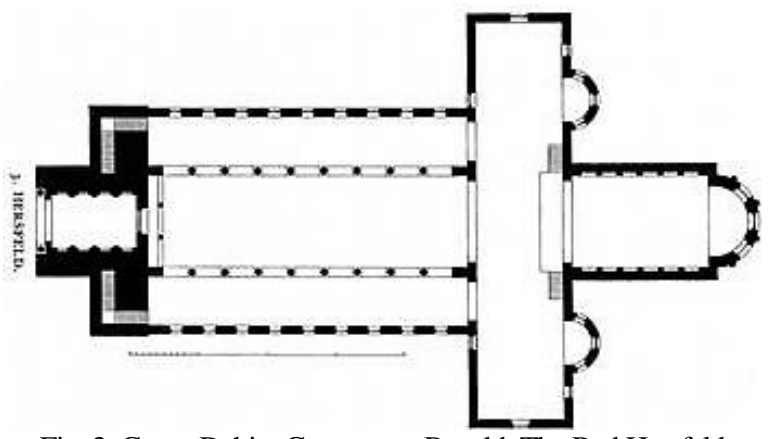

Fig. 3. Georg Dehio, Gustav von Bezold. The Bad Hersfeld Abbey Basilica plan. 1887-1901 [4]
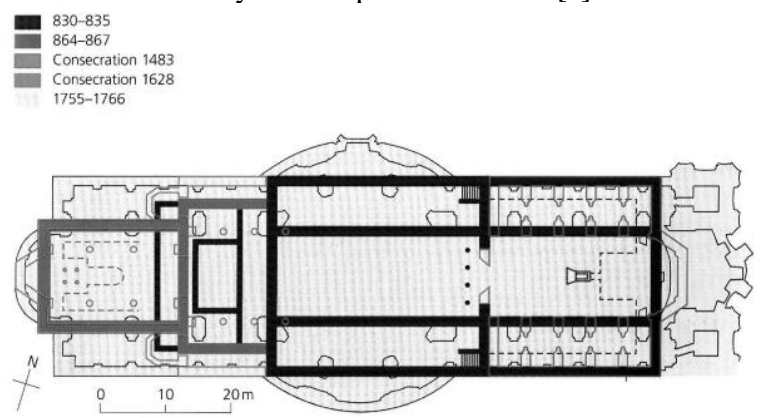

Fig. 4. Small St. Gallus and St. Otmar churches in the plan of St. Gall Benedictine monastery church of St. Gallus and St. Otmar [5, 9]
(802-817) Ratgar (Latin: Ratgarius; ?-835), applying the sample of St. Peter's Basilica in Rome (Latin: Basilica Vaticana, Basilica Sancti Petri; 324/326-349), built Ratgar Basilica (791-819), instead St. Strum Church. In the west-end of the church a transept (Latin: transeptum) was made $[19,311]$. A courtyard, surrounded by covered galleries for walk or cloisters (Latin: claustrum, French: cloître, German: Kreuzgang), was added (Fig. 2).

At Saint-Riquier (originally Latin: Centula or Centulum) Benedictine abbey (around 625, destroyed in 881), founded by Richarius (around 560-645), monastic school, library and workshop for ancient record rewriting (Latin: scriptorium) were opened. A noble Frankish poet, who served Charles the Great as a secretary, diplomat, elected abbot in 794 Saint Angilbert (sometimes known as Angilberk or Engelbert; 760-814) rebuilt Saint-Riquier Basilica (799): in the western façade the westwork (German: Westwerk) for the monumental entrance was made, but the altar was placed deep in the apse. Abbey church Saint-Riquier Basilica together with NotreDame Chapel and San Benedetto Basilica formed the monastery's complex around the courtyard (Fig. 3).

In Saint Peter and Saint Paul Benedictine Monastery (Latin: Laureshamense Monasterium; 764) of Lorsch Princely Abbey (German: Reichsabtei Lorsch, now in Austria) (Fig. 1) there was a library with ancient authors' writings and a workshop for it rewriting. In 774, Saint Nazarius Curch (German: Katholischen Pfarrei St. Nazarius Lorsch) was consecrated. King of the Franks from 768, King of the Lombards from 774 Charles the Great took part in this event. After becoming the first Emperor of the Holy Rome, he paid a special attention to the abbey church reconstruction. In 775, he also awarded the status of Imperial Abbey to the Princely Abbey of Hersfeld (German: Reichsabtei Hersfeld; now HesseNassau), founded by Saint Sturm and Saint Boniface. In 780, pilgrims started to visit Hersfeld Abbey. A new basilica was built to extend the abbey's building, but in 1038, a fire destroyed this basilica. Bad Hersfeld Abbey Church reconstruction was started immediately, and in 1144 triple-nave basilica with a deep apse and extra altars in the cross-part (Fig. 4) were consecrated.

In the Benedictine monastery of Saint Gall (German: Fürstabtei St. Gallen; 719) (Fig. 1), where monks were engaged into science, crafts and farming, the first abbot of the Abbey of Saint Gall Otmar founded a school, made a library and built a stone church (719). In 819, Charles the Great's advisor Abbot Heito (also Haito; 762-835/836) from Reichenau Abbey (German: Kloster Reichenau, Latin: Monasterium Augiensis) (Fig. 1) under Abbot (816-837) Gozbert's guidance drew the idealplan of Saint Gall Abbey (German: St. Galler Klosterplan). 


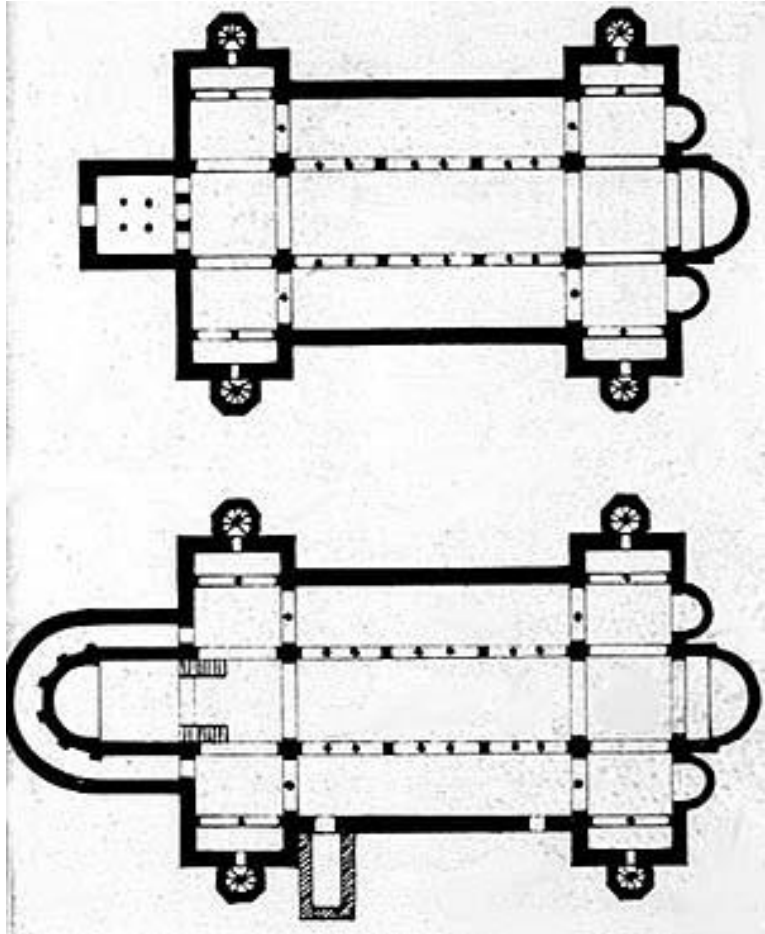

Fig. 5. The evolution of Hildesheim St. Michael's Church plan [online 19.06.2017, source:

http://www.pitt.edu/ tokerism/0040/images4/ar.96.04052.jpg]

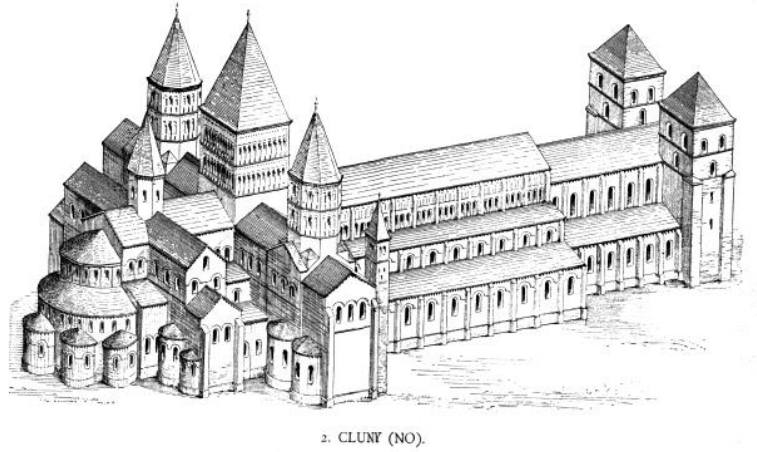

Fig. 6. Georg Dehio, Gustav von Bezold. The drawing of Basilica Cluny III reconstruction. 1887-1901 [4]

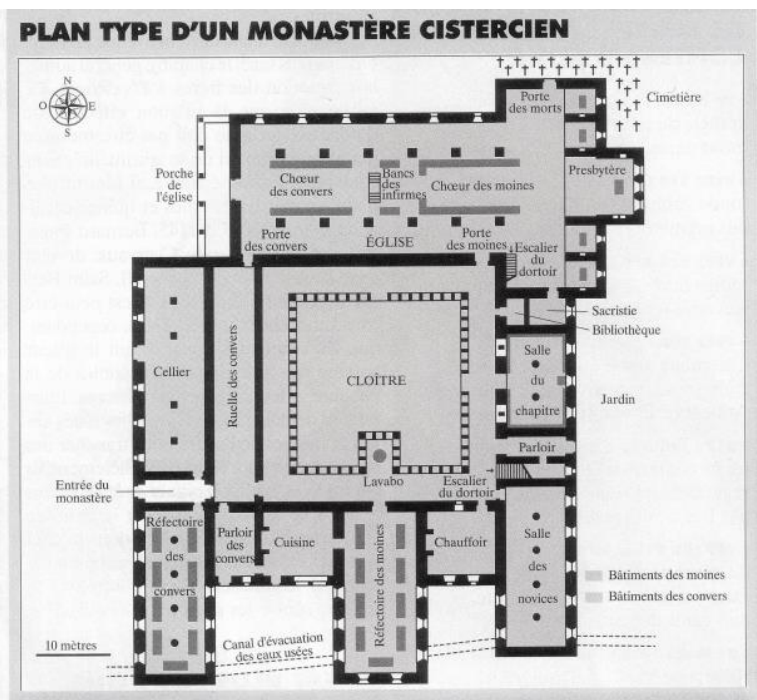

Fig. 7. The functional scheme of Cistercian monastery complex [online 19.06.2017, source: http://www.lille.iufm.fr/passages/ article.php3?id_article=25]
In a fortified rectangular territory craftsmen's workshops, travellers' accommodation, monastic school [12, 24], hospital, library, gardens, stables were placed. Blocks of two, four or more buildings became a unit of regular planning residential structure. In the southern side of the courtyard with a fountain or cross and the cloister garden (German: Kreuzganggarten) was surrounded by dormitory, refectory (Latin: Refectorium) or canteen, kitchen, but southwards administration buildings, homes and household buildings were grouped. One part of the abbey territory was not built up in order to preserve the link with nature. In the easterncorner, a garden for herbs was envisaged (German: Kräutergarten). In the south-east part, where monks' cemetery (German: Obstgarten auf dem Friedhof der Mönche) was situated, a vegetable garden (German: Gemüsegarten) and apple orchard was made [11, 13, 16, 17, 19] (Fig. 5). Gorbert started wide changes: eastwards from the church he created an infirmary (Latin: infirmarium) and garden for sick monks, northwards - abbot's block, school and guesthouses, but a little further - stables and servants' homes. However, the ideal-plan was not implemented. St. Otmar Church was rebuilt (830-835) into a triplenave building, which joined together (864-867) with St. Gall Church, created a long two-division basilica with a wide nave and big apse for the chancel, where the altar for St. Peter and St. Paul was placed. However, the building did not have the transept. On the western façade of Benedictine monastery church of St. Gallus and St. Otmar (German: Stiftskirche St. Gallus und Otmar) (Fig. 6) [5, 10] a pair of towers was made - on the top part of one of the towers there was the altar of St. Michael the Archangel, but on the other - the altar of St. Gavril the Archangel. The abbey was included in the common defence system with the town and it affected the fortified territory planning.

In the East, the lands were conquered, and in Northern Italy the Romanesque construction forms, whose prototypes could be found in Asia Minor and Syria, emerged. In German lands, innovations were introduced through Lombardy and Ravenna, but later also through Italy, France and Spain. In 950, in Gernrode (German: Gernrode) Virgin Mary and Apostle Peter's Collegiate Church (German: Kollegiatstift, Chorherrenstift) obtained Saint Cyriakus' relics (Cyriak; about 303). In 965, relics were buried in the central part of triple-nave building, and in aisles of Saint Cyriakus Church (German: Stiftskirche St. Cyriakus; 959-965) matronaea (German: Empore, Latin: matroneum, matronaeum) were made. In the $10^{\text {th }}$ century, in the region to the north from the Alps it was a novelty. In the eastside of the basilica, where the nave was crossed the transept, two small apses were made in transept. Behind the transept under the chancel a place of grave covered 
with vaults and the crypt (Latin: crypta) was built. A cylindrical staircase tower surrounded the westwork from each side. In the $12^{\text {th }}$ century, Saint Cyriakus Church was partly rebuilt: in the western side behind the transept the chancel, apse and triple-nave crypt were placed in addition, but staircase towers raised for two floors. Matronaeas were replaced in the aisle. An open transept directed towards the middle cross.

In Lower Saxony Bishop of Hildesheim (852-874) Altfrid built the Dome (German: Mariendom; 872), which was a triple-nave basilica with a westwork. On a hill, Bishop of Hildesheim (993-1022) Bernward built a small Saint Cross Chapel, consecrated on September 10, 996. In 1010, in Hildesheim the new abbey church construction began. On St. Michael's Day, on September 29, 1015 the western crypt for Bernward's burial place was consecrated (Fig. 7) and the patron was stated. It is possible that Bernward not only suggested building St. Michael's Church (German: Michaeliskirche; 1010-1033), but he was also its architect, who has given an important contribution to church building formation. It is considered, that architect could also have been the first abbot of the new Benedictine monastery (1022-1030) Goderamnus. In 1033, St. Michael's Church was consecrated by Bishop of Hildesheim Gotthardus (Latin: Godehardus Hildesheimensis; 960-1038) [18, 53]. Nevertheless, the building in 1034 and 1186 was destroyed by fire. The middle-nave columns were replaced, and around 1230 the triple-nave room was covered with a painted wooden ceiling. The main entrance on the side of the building from the market confirmed decrease of the westwork importance in architecture of churches. Saint Cyriakus Church and St. Michael's Church obtained a simple, thoughtful solution with monumental towers, which dominated in urban silhouette.

In the middle of the $11^{\text {th }}$ century, in Western Europe basilicas stone vaults building began in order to replace the wooden ceiling of the nave [18, 46]. Abbot (930-936) Ratfredus rebuilt Farfa Abbey, but Abbot of Farfa (1049-1089) Berard I it changed into a place for intellectual activities. In 1013, Bishop Alibrando founded the Benedictine monastery in Florence, and instead of the $3^{\text {rd }}$ century building, he started to build the triple-nave San Miniato al Monte Basilica (1013-1207) without the transept, adding to it the sacristy, chapel and belfry. The crypt was covered with cross vaults $[17,30]$. A new type of sacral buildings was created.

In the $10^{\text {th }}$ century the abbot of the Princely Abbey of Fulda became the Benedictines' leader in German lands on the left bank of River Rhine and in Gaul, and Benedictines arrived in Burgundy, the eastern region of France. On September 11, 910 in Saône-et-Loire on the base of the Clugny Villa Duke of Aquitaine (893918) Guillaume le Pieux, subjugated to pope, founded
Cluny (also Cluni) Abbey. There was a different organizational structure: monks lived in compliance with the Regula Benedicti, but between their prayers, they did some physically light work - made different objects for church, did some gardening, read books, rewrote and illustrated books. Under the first abbot of Cluny (909-926) Berno (French: Bernon) guidance the earliest basilica Cluny I (927) was built. It was the world's largest church until St. Peter's Basilica construction began in Rome. In 931, Pope (931-935) Ioannes XI awarded the second abbot of Cluny (927942) Odo (French: Odon) the privilege to take over in his jurisdiction abbeys which were going to implement the Cluniac Reforms - envisaged to maintain discipline in abbeys, observe statutes of the Order and unity in the building planning. French bishops, who did not want to lose their impact on abbeys, put up their strong resistance. However, the reform promoted formation of a union around Cluny Abbey as a centre, which in 939 obtained independence from secular power, implemented transition a self-sufficient agricultural unit and was the leading one among the seven-abbey union (Latin: congregatio). Abbeys obtained political support. In the development of abbey church type the social function became important. Under Abbot of Cluny (964-994) Maiolus (Maieul, Mayeul, Mayeule) and Abbot of Cluny (994-1049) Odilo guidance the church was rebuilt, and basilica Cluny II (955-981) was made. The spatial composition of volumes was subjected not so much to liturgy of the abbey and monks' seclusion, but rather to ideology and services to large-scale pilgrims' flow. The greatest part of Burgundy and French abbeys were included in the union, and the total number increased up to 65 . During Abbot of Cluny (1049-1109) Hugh (French: Hugues de Cluny) reign Cluny Abbey obtained authority and a huge impact on society. It promoted by strictness, obedience, charity, hospitality. Cluny Abbey prospered under Roman Pope's subjugation, and the fast development of St. Peter's and St. Paul's Abbey community caused a need for large buildings. Monk Guncon, who in his dreams saw St. Peter, proposed to extend the basilica, so that it would be possible to gather a thousand monks at the same time. On September 30, 1088 construction of Abbey of Cluny III (1088-1220) for the centre of the abbey's complex was started. The planning of $187 \mathrm{~m}$ long five-nave Saint Michael Basilica (1088-1131) reminded of the archbishop's cross. At the end of the middle-nave behind the transept a circular passage around the ridge was made, and the ambulatory or curving aisle in the apse that passes behind the altar was surrounded with the chevet of five small apse-chapels - apsidioles for the altars, in 1095 were consecrated. The church had five towers - one in the centre of the middle cross, two above the big transept, and two more - at the western 


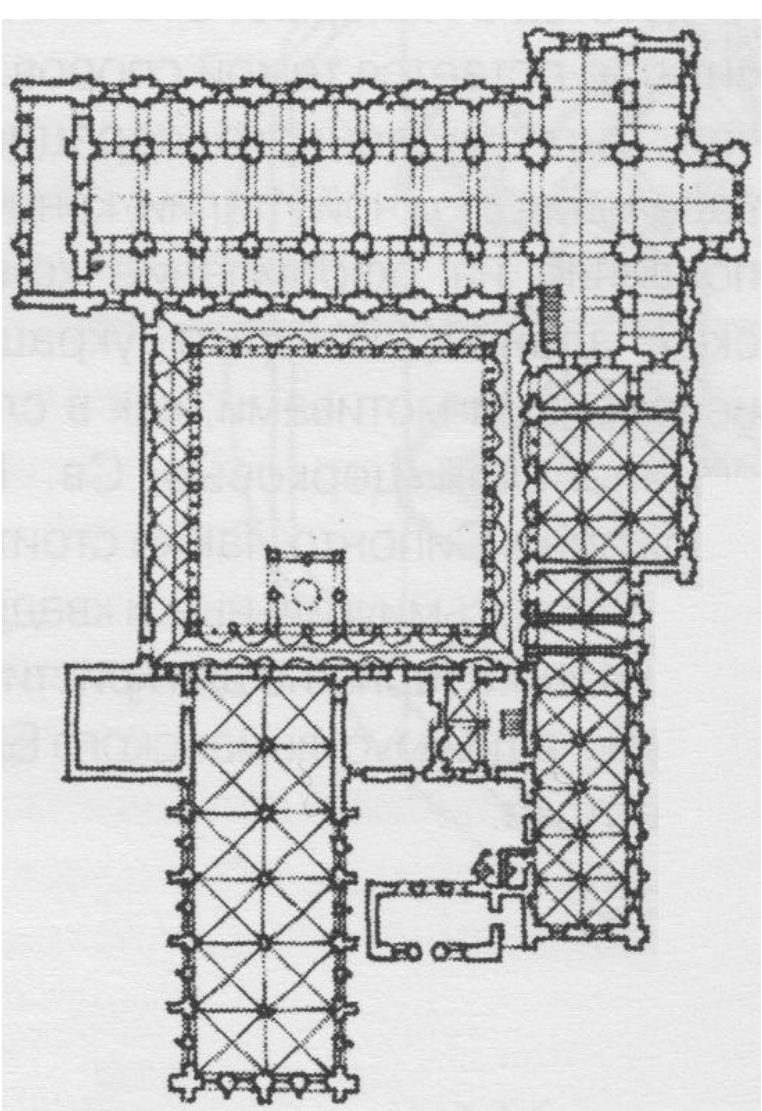

Fig. 8. The floor plan of Fontenenay Cistercian abbey complex and basilica $[19,401]$

acade (Fig. 8), where in front of the main entrance the perspective portal was built for the first time and a closed anteroom - a long triple-nave narthex (German: Nartex) was made. Around 1080-1090 a Benedictine monastery church type was created, and it was applied in several places in Europe. With the help of the pope, abbeys, worked in isolation, were included in the union by Clunians, in which around 1100 there were about a thousand reformed abbeys. Abbot of Cluny obtained a spiritual supreme command and around the $12^{\text {th }}$ century, several thousand monks were united in a religious brotherhood. On October 22, 1131 the abbey church of Cluny, consecrated by Pope (1130-1143) Innocentius II, in terms of significance from 1122 till 1156 was the next one after the Christianity centre in Rome [18, 50].

Previous researches on abbey churches in Western Europe: in Georg Dehio's and Gustav von Bezold's "Kirchliche Baukunst des Abendlandes" [4], issued in Stuttgart 1887-1901, graphical materials of cult buildings - plans, cuts, façade drawings have been collated, Josef Grünenfelder has dedicated to St. Gallus Abbey Basilica the edition "St. Gall Cathedral. The former Benedictine abbey church of St. Gallus and St. Otmar" (2009) [5]. Karl Schmuki, Ernst Tremp and Andrea Grandjean have collated the history of St. Gallus school in the book "Das Kloster St. Gallen und seine Schulen" (2009) [12], but Karl Schmuki, Ernst Tremp and Nina Otto's book
"Heilkräuter und Gartenanlagen im Kloster St. Gallen" (2010) [11] is dedicated to the abbey's gardens. In Rolf Toman, Alan Bednorz and Barbara Borngässer's book 'Cathedrals and Churches of Europe" (2015) [14] broad information on churches and cathedrals in Europe has been included. Previous researches on monastery churches in Livonia: the famous fortress researcher in the Baltics, Estonian historian of art, Professor of Tartu University Dr. phil. Armin Tuulse (1907-1977) has collated the data on monastery buildings in Estonia and Latvia in the edition "Die Burgen in Estland und Lettland" (1942) [16]. The outstanding Latvia historian, prof. emeritus Dr. Indriķis Šterns (1918-2005) of Muhlenberg College, US the information about monastery buildings has included in monographs "Latvijas vēsture. 1290-1500" /History of Latvia. 1290-1500/ and "Latvijas vēsture. 1180-1290. Krustakari" /History of Latvia 1180-1290. Crusades/ in the edition "Senā Rìga" /Ancient Riga/, issued by Latvia Institute of History. The encyclopaedia "Latvijas 12. gadsimta beigu-17. gadsimta vācu pilı leksikons" /Lexicon of late $12^{\text {th }}-17^{\text {th }}$ century German Castles in Latvia/ (2004) [3] was compiled by archaeologist prof. Dr. habil. hist. Andris Caune and Dr. Ieva Ose and has been published into series of books "Latvijas viduslaiku pilis" /Medieval Castles in Latvia/. The encyclopaedia "Latvijas viduslaiku mūra baznīcas. 12. gs. beigas - 16. gs. sākums" / Medieval stone churches in Latvia. Late 12th centearly 16th cent. / (2010) [2] compiled by Andris Caune and Ieva Ose, includes broad information. Prof. Dr. hist. Ilgvars Misāns and asoc. prof. Andris Šnē of Latvia University History and Philosophy Faculty have prepared materials for seminars in Medieval History of Western Europe "Klosteris, pils un pilsēta" /Abbey, Castle and City/ (2004) [8]. Previous researches on monastery churches in the State of the Teutonic Order: Dr. Liliana KranzDomasłowska (b. 1954) has included the information on monastery churches in the research about double cities "Double cities in the Teutonic state on the example of Toruń" (2013) [7].

Research problem - the impact of medieval monastery complexes on the origins of Livonian and Prussian urban environment and building formation has been studied insufficiently. Research novelty the identity of Livonian and Prussian monastery churches' architecture and impact of monastery building complexes on the urban environment formation origins in the Baltic during the $13^{\text {th }}-14^{\text {th }}$ century have been analysed in European and regional context. The goal of the research - analyse the peculiarities of architecture and planning of monastery churches, as well as the monastery complex influence on establishment of the Teutonic Order's fortified power centres and town planning of Livonia and Prussia during the $13^{\text {th }}$ and 


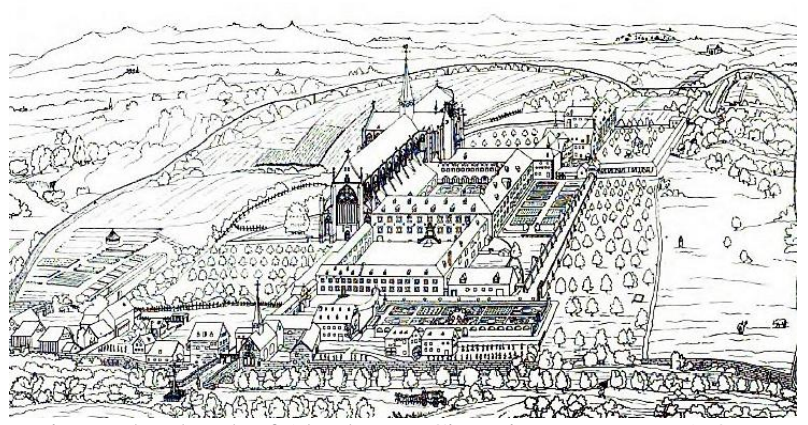

Fig. 9. The church of Altenberger Cistercian monastery. 1707 [Source: Die Kunstdenkmäler der Rheinprovinz]

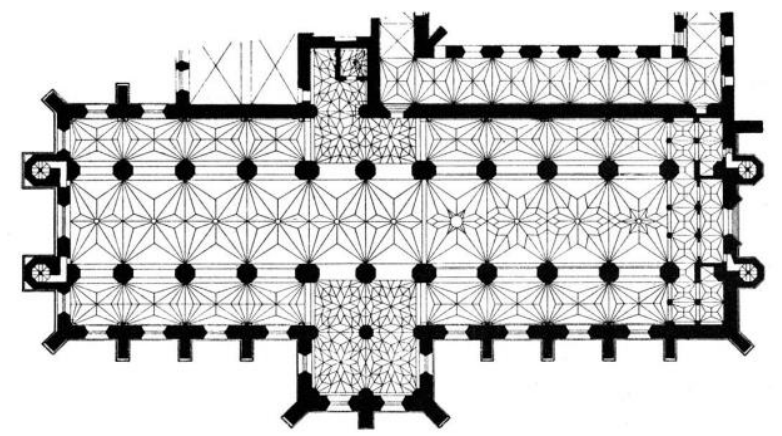

Fig. 10. Georg Dehio, Gustav von Bezold. The Cathedral Basilica of the Assumption of the Blessed Virgin Mary in Pelplin. 1887-1901 [4]

$14^{\text {th }}$ centuries in order to determine the common and different characteristics. Main methods appliedthis study is based on research and analysis of archive documents, photo materials, projects and cartographic materials of urban planning, as well as inspection of buildings in nature, study of published literature. Results - study of architecture, layout formation and structure of Cistercian monastery churches.

\section{The Cistercian monasteries planning and structure}

Benedictine monks, who criticized crave for luxury and unwillingness to do hard work, joined in a group. In France, the Cistercian Order (Latin: Ordo Cisterciensis) under the subjugation of the Roman Catholic Church was established, and in it there was a distinct Cult of Mary. In 1098, in French Region Côte $d^{\prime} \mathrm{Or}$ the first Cistercian monastery (French: Abbaye Notre-Dame de Cîteaux) was founded. It sustained with farming and a brewery and called the New Monastery (Latin: Novum Monasterium). The base was self-sufficiency - monks had to gain their subsistence from handwork, farming and cattle breeding. Therefore, it was necessary for monastery to have waters, forests, animals, vineyards, meadows and fields away from the secular people's places of residence. Cistercians led a modest lifestyle. They observed strict Lent, worked on the farm and built monastery buildings close by energy resources rivers or brooks. To satisfy monks' basic needs the building in a farmstead consisted of a chapel and a wooden house with a bedroom, dining-room and kitchen, but during 1124-1193 stone buildings were erected. In remote areas, the third abbot of Cîteaux
(1109-1134) Stephen Harding established building of Firmitas (1113), Pontiniacum (1114), Morimond (1115) Cistercian monasteries. On 25 June 1115, Bernardus Claraevallensis (1090-1153) founded the monastery naming it Claire Vallée, which evolved into Clairvaux. This monastery building was similar. In 1118, in France Bernardus founded one of the biggest Cistercian monastery - the Abbey of Fontenay. Pope (1119-1124) Calixt II confirmed the Charta Caritatis and set requirements for room placement and functional organization of the New Monastery. It was forbidden to establish monasteries in cities, by farms and castles, but building was allowed only within the monastery territory, in which there had to be a garden, craftsmen's workshops, a water spring, homes, a chapel, rooms for catering and guest hosting. Cistercians, applying of the Benedictine monastery basilica planning as a sample, in 1135 started to build the Basilica of Clairvaux Abbey (Latin: Clara Vallis). However, Abbot of Clairvaux (1115-1128) Bernardus criticized too long and wide house. It was not allowed to place in churches expensive paintings, stained glass windows and sculptures, which disturbed concentration during prayers, but it was allowed to place the Christ the Saviour's image and paintings only on crosses made of wood. Stone belfries were forbidden in Cistercian churches, and colourful floors were not allowed [8, 193]. Monks of Cluny Abbey criticized introduced requirements. Bernardus, having borrowed the idea form ancient Greek homes, where rooms were placed around the peristyle (Latin: peristylium) or an open square yard, surrounded with the portico, developed a functional scheme (Fig. 9) for the construction of Cistercian monastery complex. In the north of the church, cloister buildings were placed: in the west cells (Latin: cella), in the south - refectories, but in the east - the sacristy, library and other rooms. In 1147, Pope (1145-1153) (Fig. 10) Beatus Eugenius III consecrated the cross-type planning Fontanay Basilica with ascetic, minimally decorated triple-nave praying room with mosaic floor, covered by high vaults. The square-type choir situated lower than the nave, separated by the colonnade on aisle each side. On the basilica south side the cloister took from the courtyard to square planning Hall of Priests' Chapter, surrounded by the portico. In Lower Saxony westwards from Hannover, during economic boom in the first half of the $13^{\text {th }}$ century Loccum Cistercian monastery (German: Kloster Loccum; 1163) wooden houses were replaced with a stone building complex, which made according to the functional scheme [6, 345]. Cistercians gave riches and plots of land, and allowing deviations from original principles and differences between Cistercians and Benedictines decreased. After Bernardus Claraevallensis' death, construction volumes of Cistercian monastery buildings increased. 


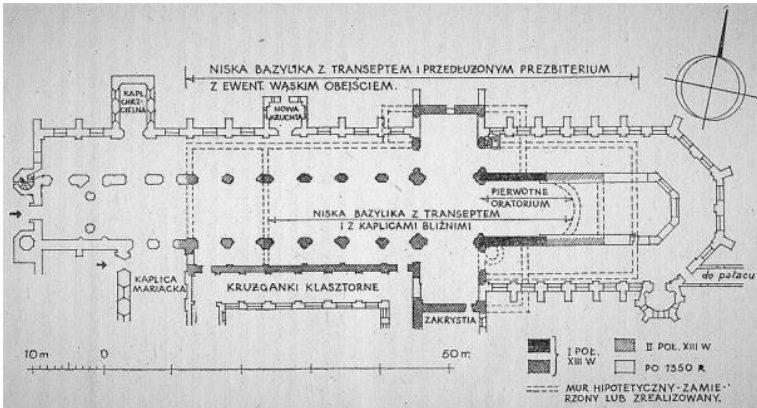

Fig. 11. The development of Cistercian monastery basilica in Oliwa. [online 19.06.2017, [http://www.dawnaoliwa.pl /bibloteczka/1956_oliwa/kosciol_a.jpg]

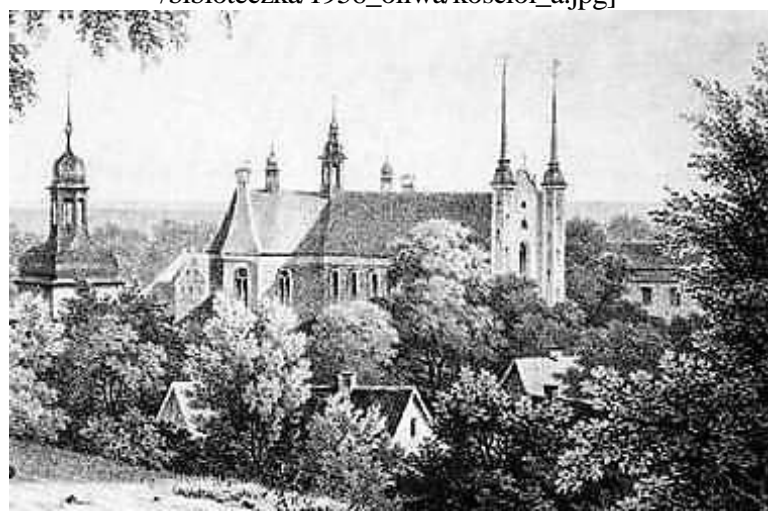

Fig. 12. Graphic artist Albert Wilhelm Adam Juchanowitz (1817-1863). The Holy Trinity, St. Virgin Mary and St Bernard's Church of Oliwa Cistercian monastery in 1574. Lithogrph of Friedrich Heinrich Bils (1801-1853). 1838 [Oliwa w starych sztychach. (1996) Gdańsk: Oficyna Czec.;

http://www.dawnaoliwa.pl/wydawcy/sztychy/01d.jpg]

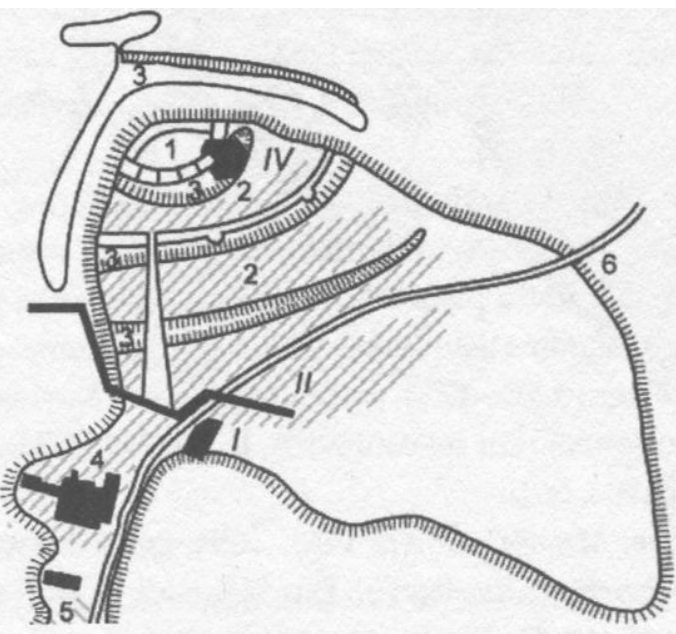

LIHULA IM MITTELALTER

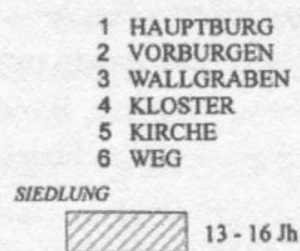

Fig. 13. The situation plan of Leale fortress and Cistercian monastery $[16,72]$

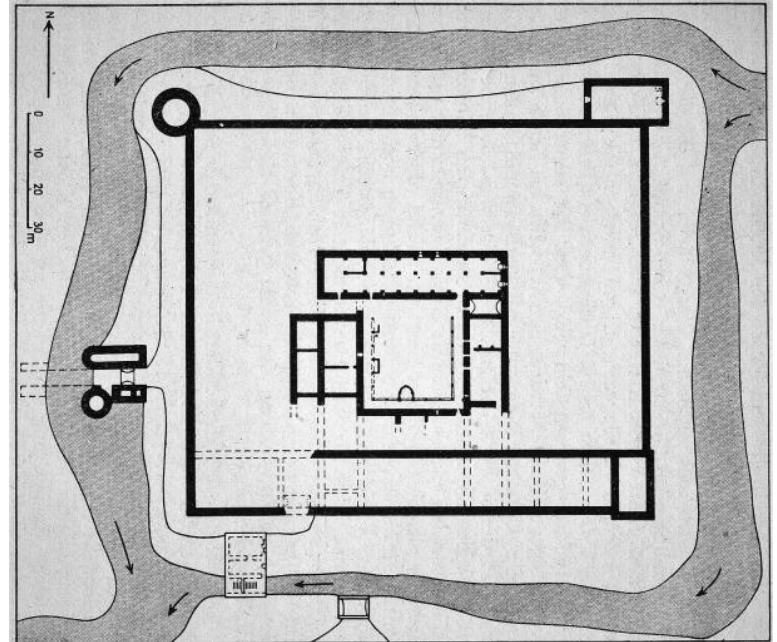

Fig. 14. The plan of Kärkna Cistercian monastery [16, 271]

Cistercian monasteries were built in lands where there was a different economic and political situation and, due to the local construction tradition, the formal differences deepened.Windows of rooms were decorated with stained glass. Floors covered colourful tiles. External walls' vertical and horizontal partition was refined with a sophisticated décor of geometrical and plant motives. Nevertheless, despite the diversity, the building of the Clairvaux and Citeaux Abbeys, and Altenberg Abbey (German: Abtei Altenberg, Latin: Vetus Mons; 1133) Church (1259-1276) $[14$, 44] (Fig. 11), now known as the Altenberger Dom (German: Altenberger Dom vai Bergischer Dom), took into account Bernardus Claraevallensis' directions, thus buildings were similar.

During $11^{\text {th }}-12^{\text {th }}$ century, in Europe most of inhabitants were Christians. Around 1139, Christianity was also introduced in Pomerania (Latin: Pomerania, German: Pommern, Polish: Pomorze). In 1175, Kobitzow (Colbitzow till 1945, Polish: Kotbaskowo) monastery monks from Stettin (Latin: Stetinum, Sedinum, Polish: Szczecin) Region arrived in Pomerania to carry out pastoral case. In 1185, in confluence of the Rivers Motława and Leniwka not far from Danzig (Polish: Gdańsk) an oratory was built with the help of Duke Sobiesław I Gdański (Latin: Sobieslaus, 1130-1187). On July 2, 1186 Cistercian monastery "Beatae Mariae de Oliva" (German: Kloster Oliva, Polish: Opactwo Cystersów $w$ Oliwie) was founded, and on March 18, 1188 Duke of Pomerania, regent of Pomerelia (1180-1207) Sambor I handed over to monks the ownership statement. A church (kościót pw. św. Mikołaja; 1190) was founded in honour to seafarers' patron Nikolaus von Myra. In 1215, in Danzig the centre of Cistercians monasteries was established.

In 1276, on the left bank of the Weichsel southwards from Danzig, monks of Doberan Abbey started to build a red brick complex according to the functional scheme - Pelpin (Latin: Polplinum) 


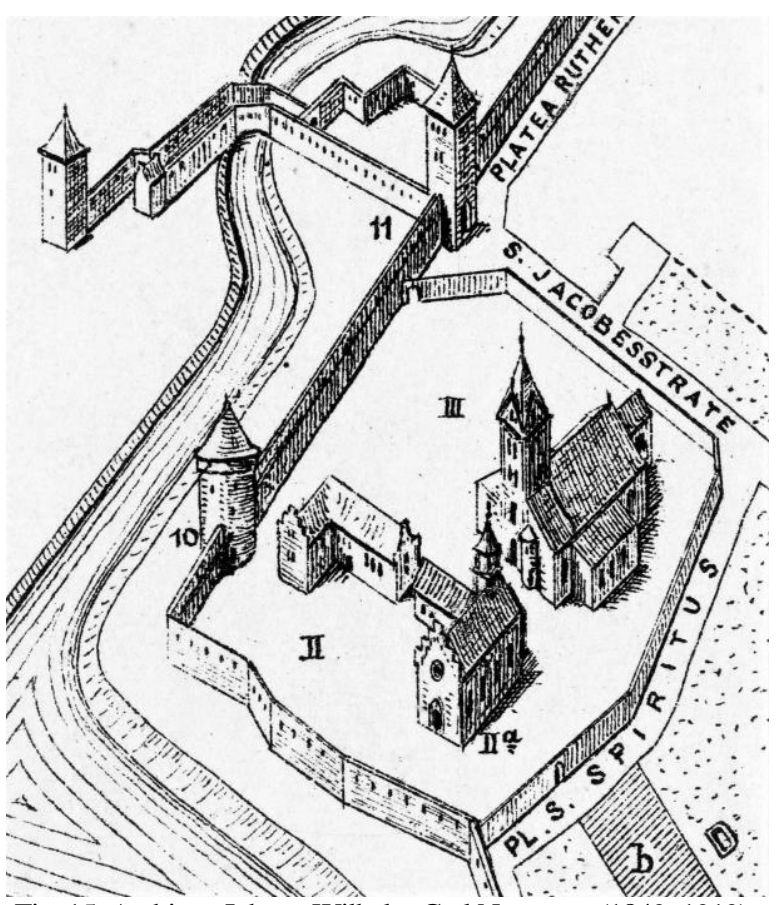

Fig. 15. Architect Johann Wilhelm Carl Neumann (1849-1919). A fragment of Riga reconstruction plan with Riga Archbishopric Centre's building around 1400: the monastery church of St. Mary Magdalene near St. Jacob's Church. 1889 [13]

Abbey (1258-1823). In 1824, a triple-nave basilica without a tower became the Cathedral Basilica of the Assumption of the Blessed Virgin Mary (Polish: Bazylika katedralna Wniebowzięcia Najświętszej Maryi Panny w Pelplinie) (Fig. 12), whose chancel was made in 1276-1294 [15, 245]. In 1224 and 1234-1236 triple-nave Church of Oliwa was burnt down by Prussians, but after the third fire in 1350 the Holy Trinity, St. Virgin Mary and St Bernard Church (Polish: kościót pw. Trójcy Świętej, NMP $i s ́$. Bernarda) were restored as a triple-nave basilica with a cross-nave and extended chancel (Fig. 13). The main entrance in the western façade was emphasized with high twin towers (Fig. 14).

\section{The Cistercian monastery church planning and structure in Livonia and the State of the Teutonic Order}

In the middle of the $12^{\text {th }}$ century, the Holy Roman Empire started to spread Christianity also in the West Slavs, Balts and Baltic Finns' lands on the south coast of the Baltic Sea. For colonization churches, abbeys and towns were set up. In Livonia, due to frequent wars Cistercian monasteries were used for defence and refuge. Alt-Dünamünde (Latvian: Daugavgrīva) Cistercian monastery in a strategically significant place not far from the Port of Riga became an important support site for knights arriving in Livonia and leaving it [6, 354]. On May 26, 1305 the Teutonic Order for the river estuary's surveillance bought the monastery $[9,70]$. The building, surrounded with a ditch full of water, was converted into the commander's residence (1305-1560), where after 1329 a convent of 12 brothers-knights was established [3, 133], preserving monastery's planning, as well as the placement of dining-rooms and the chapel in the south-east corner [6, 355]. In the Leale Bishopric (episcopatus Lealensis) or Estonian Bishopric (Episcopatus Estiensis or episcopatus de Hestia; 1211-1224) centre the Bishop's residence (1220-1238) was built: a courtyard, made up by a defensive wall, customized to the relief, building up houses on the yard side. In the $13^{\text {th }}$ century, in Leale (Estonian: Lihula) the first church was built on the main building's south wing, to which the separate courtyard was detached with the defensive wall and residential blocks. The planning of fortified courtyard obtained sequestered, functionally different zones. Near the fortress urban settlement and the Cistercian monastery (destroyed in 1570) were formed (Fig. 15). In Falkenau (Falkenau, Valkena) by the River Emajegi, Bishop of Tarbatu (1224-1248) Hermann I (German: Hermann von Buxhövden) founded Kärkna Cistercian monastery (kloster Kärkna, Kaerkna klooster; 1233/1234-1558). Construction volume blocks were placed around the courtyard and the rectangular planning building reminded of a fortress of the Teutonic Order [1, 18].

In 1246, in Lübeck a monastery for Cistercian nuns was built. Pope (1254-1261) Alexander IV in his letter of August 2, 1255 mentioned a place in Riga at St. Jacob's (also St. James's) Church (German: Jakobskirche, Latvian: Sv. Jēkaba baznīca), where a Cistercian monastery has to be established for citizens' unmarried daughters and widows' care. He mentioned monastery's privileges and the Regula Benedicti, awarded to it. Formation of the monastery has to be related to May 1, 1257 [2, 314]. Westwards from the St. Jacob's Church entrance St. Mary Magdalene's Church (Latvian: Rìgas Svētās Marijas Magdalēnas Romas katolı baznīca) and buildings in monastery's courtyard created a partition into two functionally different zones. In 1259, Archbishop of Riga in the subsidy document confirmed the present to the monastery - the courtyard at St. Jacob's Church. The Canonical Chapter allowed Cistercian sisters to use the courtyard while St. Mary Magdalene's Church of the monastery was built. In the document of 1262 it was reported that a new wall would be built in the suburbs of Riga at the defensive wall around the monastery, but buildings at the cemetery of St. Jacob's Church would be knocked down [2, 282]. Since 1256 the Cistercian monastery existed in Kokenhusen (Latvian: Koknese) urban settlement, to which on July 13, 1277 the Riga City Statutes were awarded. In Lemsal (Latvian: Limbaži) St. Anna's monastery for Cistercian sisters was founded before 1450 [2, 200].

On the River Weichsel right bank, at the Old Town of Kulm (Polish: Chetmno) defensive wall $\left(13^{\text {th }}-15^{\text {th }}\right.$ cent.) northwest corner the Monastery of 
the Sisters of Mercy for Cistercian nuns (German: Frauenkloster Chetmno, also Kloster Kulm, Polish: Zespót klasztorny Sióstr Miłosierdzia w Chetmnie; 1261, 1280-1330) and St. John the Baptist and St. John the Evangelist's Church (Polish: kościót śś. Jana Chrzciciela i Jana Ewangelisty; 1280-1330) were built. It is considered that the lower part of the church was completed in 1310-1320, but the upper part around 1330-1340.

\section{Conclusions}

1. In Livonia and the State of the Teutonic Order, Cistercian and Augustinian monasteries were founded. The convent building complex was developed, but the monastery church was small.

2. Kärkna Cistercian monastery, as well as AltDünamünde Cistercian monastery was built for the Baltic land subjugation as the places of residence for monks-knights. In Riga Alt-Dünamünde Cistercian monastery, houses were arranged around the courtyard, but monastery buildings for Cistercian nuns at St. Jacob's Church made a fortified yard divided into two functionally different zones. St. Mary Magdalena's Church was built westwards from the entrance of St. Jacob's Church. In Kokenhusen, as well as in Lemsal buildings of St. Anna's Cistercian Monastery might have formed a fortified yard.

3. In the State of the Teutonic Order the Monastery of the Sisters of Mercy for Cistercian nuns was built in the north-west corner of the Old Town of Kulm by the defensive wall $\left(13^{\text {th }}-15^{\text {th }}\right.$ cent. $)$, where also St. John the Baptist and St. John the Evangelist's Church was situated. Buildings of the Monastery of the Sisters of Mercy created a fortified yard.

\section{References}

1. Benninghofens, F. Pilis kā galvenie atbalsta punkti vēlo viduslaiku aizsardzības sistēmā Vācu ordeña valstī Prūsijā un Livonijā. In: Latvijas viduslaiku pilis, VII. Pētījumi un avoti par Livonijas ordeņpilīm. Rīga: Latvijas vēstures institūta apgāds, 2011, 9.-51. pp. ISBN 978-9984-624-23-9.

2. Caune, A. Ose, I. Latvijas viduslaiku mūra baznīcas. 12. gs. beigas - 16. gs. sākums. Enciklopēdija. Rīga: Latvijas vēstures institūta apgāds, 2010. 511 pp. ISBN 978-9984-824-17-8.

3. Caune, A., Ose, I. Latvijas viduslaiku pilis, IV. Latvijas 12. gadsimta beigu-17. gadsimta vācu piḷu leksikons. Rīga: Latvijas vēstures institūta apgāds, 2004. 591 pp. ISBN 9984-601-07-2.

4. Dehio, G., von Bezold, G. Kirchliche Baukunst des Abendlandes. Stuttgart: Verlag der Cotta'schen Buchhandlung, 1887-1901.

5. Grünenfelder, J. St. Gall Cathedral. The former Benedictine Abbey Church of St. Gallus and St. Otmar. Berne: Society of the History Swiss Art, 2009. 40 pp. ISBN 978-3-85782-847-8.

6. Heinrici Chronicon, Rīga: Zinātne, 1993. 453 pp. ISBN 5-7966-0326-4.

7. Kranz-Domaslowska, L. Double cities in the Teutonic state on the example of Toruń. In: RIHA Journal 0068, 8 March 2013.

8. Misāns, I., Šnēē, A. Klosteris, pils un pilsēta. Materiāli semināriem Rietumeiropas viduslaiku vēsturē. Rīga: Latvijas Universitāte, 2004. 288 pp. ISBN 9984-770-19-2.

9. Ose, I. Bīskapa Alberta laikā celtās Latvijas pilis. In: Senā Rīga. Rīga: Latvijas vēstures institūta apgāds, 2000, 65. 78. pp. ISBN 9984-601-50-1.

10. Rahn, J. R. Geschichte der Bildenden Künste in der Schweiz. Von den Ältesten Zeiten bis zum Schlusse des Mittelalters. Zürich: H. Staub, 1876. 888 S.

11. Schmuki, K., Tremp, E., Otto, N. Heilkräuter und Gartenanlagen im Kloster St. Gallen. St. Gallen: Verlag am Klosterhof St. Gallen, 2010. 111 S. ISBN 978-3-906616-96-4

12. Schmuki, K., Tremp, E., Grandjean, A. Das Kloster St. Gallen und seine Schulen. St. Gallen: Verlag am Klosterhof St. Gallen, 2009. 191 S. ISBN 978-3-906616-89-6

13. Schröder H. Riga im Wandel der Zeiten. Tilsit, Leipzig, Riga: Holzner Verlag, 1942, S. 57.

14. Toman, R., Bednorz, A., Borngässer, B. Cathedrals and Churches of Europe. Potsdam: h. f. ullmann publishing GmbH, 2015. 400 pp. ISBN 978-3-8480-0690-8

15. Torbus, T. The Architecture of the Castles in the Prussian State of the Teutonic Order. In: Archaeology and Architecture of the Military Orders. New Studies. London, New York: Routledge, Taylor \& Francis Group, 2016, 219.249. lpp. ISBN 978-1-4724-2053-4, ISBN 978-1-3155-6749-5

16. Tuulse, A. Die Burgen in Estland und Lettland. Dorpat: Dorpater Estnischer Verlag, 1942. 432 S.

17. Zucconi, G. Firenze guida all'architettura. Verona: Arsenale Editrice, 2007. 147 pp. ISBN 978-88-7743-146-2

18. Гнедич, П. П. Мировая архитектура. Москва: ЭКСМО, 2012. 230 с. ISBN 978-5-699-56587-0

19. Чинг, Ф. Д. К. Всемирная история архитектуры. Сооружения всех стран и континентов за 6000 лет: от IV тысячелетия до н. э. до наших дней. Москва: Астрель, 2011.784 с. ISBN 978-5-271-35405-2

\section{INFORMATION ABOUT AUTHOR:}

Silvija Ozola, Mg. Arch, Assistant Professor of Riga Technical University (RTU), Latvia. Graduated the Faculty of Building at Riga Polytechnic Institute, obtained a certificate in the architecture in 1980. Obtained the diploma of Education and Sport specialist at Latvian Academy of Sport Education in 2003. Obtained a master degree in architecture at RTU the Faculty of Architecture and Urban Planning in 2008. Graduated a doctor degree of Architecture theoretical course of study at RTU the Faculty of Architecture and Urban Planning in 2010. Academic work experience: lecturer at Riga Building College (2005-2010), lecturer at RTU 
(2006-2016); Assistant Professor at RTU since 2016. Professional work experience: architect at Design Institute „Lauku projekts” („Rural Project”) (1980-1983); architect at Architect's Design Group in Liepaja District (1984-1990). The author of village development projects, as well as projects of public and private buildings. The author of more than 80 publications about landscape architecture, urban planning, history of architecture, published in Latvia, Estonia, Poland, USA, Italy, Germany, Russia. Research interests - art, music, landscape architecture, urban planning, history of architecture. E-mail: ozola.silvija@inbox.lv

Kopsavilkums. Pārliecināti kristieši kḷuva par mūkiem un nomaḷās vietās vai pie lielceḷiem sāka reliǵiskām, izglītojošām un sociālām vajadzībām dibināt klosterus, kur organizēja dievkalpojumus un skolas, pārrakstīja grāmatas, nodrošināja ceḷiniekiem naktsmītnes, aprūpēja atraitṇus, bāreṇus, dziedināja slimus ḷaudis. Neizmantojot betonu, cēla vienveidīga plānojuma monumentālas klosteru baznīcas ar puscilindrisku kori jeb altārdaḷu (latīṇu: presbyterium) austrumgalā, koka griestiem, masīvām sienām, atturīgu dekoru. Baznīcu telpas ar nelieliem logiem bija tumšas un noslēpumainas. Ideoloǵijas un mirušo piemiņas kulta ietekmē baziliku plānojums kḷuva izstiepts: vidusjoma austrumgala noslēgumā altārtelpas pusapḷa plānojuma nišā jeb apsīdā izveidoja paaugstinājumu altārim, sienās izbūvēja logus. Rituāla procesijas organizēšanai ierīkoja kapelas, papildus altārus šḳērsjomā (latīṇu: transeptum). Deambulatorijs jeb ieeja apsīdā savienoja abus sānjomus un l̦āva apiet apkārt altārtelpai. Celtne ieguva latīṇu krusta aprises, taču noteicošā nebija simbolika, bet gan telpas funkcionalitāte. Transepts, ko uzskatīja par pakārtotu, kḷuva nozīmīgāks par vidusjomu un kopš 5. gs. bija vajadzīgs ugunsdrošu pārsegumu izveidei, jaunu plānojumu un velvju risinājumu meklējumiem. Ekonomika 9. gs. sākumā veicināja tirdzniecību, svētceḷnieku kustību, pilsētu un kultūras atdzimšanu. Katedrālēm altārdaḷa bija neliela, bet klostera baznīcām, pagarinot sānjomus, altārdaḷa ieguva neparastus izmērus. Lielajās abatijās izveidoja divus sānjomus, bet sānu apsīdas nodalīja no centrālās arkādes. Svētās Romas pirmais (800-814) imperators (latīnu: Imperatores Romani Sacri, vācu: Römisch-deutscher Kaiser) Kārlis Lielais ar Sv. Benedikta (ap 480-547) formulētā mūku kopienas dzīvesveida reglamenta Regula Benedicti (ap 540) palīdzību radīja klosterus impērijas pārvaldes sistēmai. Latīṇu krusta plānojuma bazilikās 10. gs. rūpīgi veidoja trīsapsīdu austrumgalu dievkalpojumu norisēm, transepta dienvidu plecā bija ieeja mūkiem. Rietumu fasādē galvenās ieejas katrā pusē uzcēla torni. Ekonomikā, reliǵijā un laicīgā politikā nozīmīgie klosteri, izmantojot ietekmi sabiedrībā, ḷoti sarežğîtas evolūcijas gaitā radīja Rietumeiropā jaunu klostera baznīcas tipu.

Francijā benediktiešu mūki, kuri kritizēja tieksmi pēc greznības un nevēlēšanos strādāt grūtus darbus, izveidoja Cisterciešu ordeni (Ordo Cisterciensis), kur izteikts bija Marijas kults. Mācības pamatā lika pašpietiekamību - mūkiem iztiku bija jāiegūst no roku darba, zemkopības un lopkopības. Klosterim bija nepieciešams, lai tālu no laicīgo l̦aužu dzīvesvietām tam piederētu ūdeṇi, meži, dzīvnieki, plavas un tīrumi. Pirmo cisterciešu klosteri, dēvētu par Jauno klosteri (latīņu: Novum Monasterium), dibināja 1098. gadā apdzīvotā vietā Côte d'Or un uzturēja ar lauksaimniecību un alus darīšanu. Cistercieši piekopa vienkāršu dzīvesveidu, ievēroja gavēni, strādāja lauku darbus un cēla pie upēm - enerǵijas avota - lıti pieticīgas klostera ēkas pamatvajadzību nodrošināšanai: viensētā atradās kapela un koka ēka ar guḷamistabu, ēdamtelpu un virtuvi. Bernardus Claraevallensis (1090-1153) dibināja vienu no Francijā lielākajiem cisterciešu klosteriem Fontenay abatiju (1118). Pāvests (1119-1124) Calixt II apstiprināja regulu Charta Caritatis (1119) un izvirzīja prasības Jaunā klostera telpu izvietojumam un funkcionālajai organizācijai: klosterus aizliedza dibināt pilsētās, pie saimniecībām un pil̄̄m. Būvēt aț̣āva tikai klostera teritorijāa, kur bija jāatrodas dārzam, amatnieku darbnīcām, ūdens avotam, mājokḷiem, kapelai, telpām ēdināšanai un viesu uzṇemšanai. Pēc benediktiešu klostera baziliku plānojuma parauga cistercieši Clairvaux klosterī 1135. gadā sāka celt baziliku. Bernardus kritizēja pārāk garo un plato celtni, neaț̣āva tajā izvietot dārgas gleznas, vitrāžas un skulptūras, kas lūgšanu laikā traucē koncentrēties, grīdas nedrīkstēja būt daudzkrāsainas. Atḷāva novietot Glābēja Kristus portretu. Cisterciešu baznīcām aizliedza būvēt mūra zvanu torṇus. Aizguvis ideju no sengrieḳu mājokḷiem, kur telpas rindoja ap portika ietvertu atklātu četrstūra pagalmu (latīṇu: peristylium), Bernardus radīja funkcionālu shēmu cisterciešu klostera kompleksa būvniecībai: kluatra ziemelpusē izvietoja dievnamu, rietumos - celles, dienvidos - refektorijus, bet austrumos - sakristeju, bibliotēku un citas telpas. Cisterciešiem dāvāja zemesgabalus un bagātības. Piẹ̦aujot atkāpes no sākotnējiem principiem, mazinājās atšķirības starp cisterciešiem un benediktiešiem. Pēc Bernardus nāves cisterciešu klosteru celtṇu konstrukciju izmērus palielināja.

Svētās Romas impērija 12. gs. vidū kristietību sāka izplatīt Baltijas jūras dienvidu piekrastes rietumslāvu, baltu un Baltijas somu zemēs. Kolonizācijai dibināja baznīcas, klosterus un pilsētas. Bruṇiniekiem, iebraucot un izbraucot no Livonijas, par svarīgu atbalstvietu kḷuva Daugavgrīvas (vācu: Alt-Dünamünde) cisterciešu klosteris stratēgiski nozīmīgā vietā netālu no Rīgas ostas. Leales (episcopatus Lealensis) jeb Igaunijas bīskapijā (Episcopatus Estiensis vai episcopatus de Hestia; 1211-1224) uzcēla bīskapa rezidenci (1220-1238) - reljefam pieskaņota aizsargmūra pagalma pusē piebūvēja ēkas, izveidojot sētu, bet Leales (igauņu: Lihula) pilsapmetnes tuvumā uzcēla cisterciešu klosteri. Tērbatas bīskaps (1224-1248) Hermann von Buxhövden dibināja Karknas 
cisterciešu klosteri (kloster Kärkna, 1233/1234-1558), kur ap iekšpagalmu izkārtotie taisnstūra plānojuma korpusi radīja cietoksnim līdzīgu celtni. Pāvests (1254-1261) Aleksandrs IV 1255. gada 2. augusta vēstulē minēja Rīgā vietu pie Sv. Jēkaba baznīcas, lai pilsoṇu neprecēto meitu un atraitṇu aprūpei ierīkotu cisterciešu klosteri, un norādīja klostera privilēǵijas un pieškirto Regula Benedicti. Klostera ierīkošana saistāma ar 1257. gada 1. maiju. No Sv. Jēkaba baznīcas ieejas uz rietumiem Sv. Marijas Magdalēnas baznīca un ēkas veidoja klostera sētu ar dalījumu divās funkcionāli atšķirīgās zonās. Cisterciešu klosteris kopš 1256. gada pastāvēja Kokneses pilsapmetnē, kura 1277. gada 13. jūlijā ieguva Rīgas tiesības. Limbažos pirms 1450. gada dibināja Sv. Annas klosteri cisterciešu mūķenēm. Kulmas Vecpilsētas ziemeḷietumu stūrī pie aizsargmūra (13. - 15. gs.) Vistulas labajā krastā cisterciešu mūķenēm uzcēla Žēlsirdīgo māsu klosteri (poḷu: Zespót klasztorny Sióstr Milosierdzia w Chetmnie; 1261, 1280-1330) un Sv. Jāṇa Kristītāja un Sv. Jāṇa Evaṇgēelista baznīcu (poḷu: kościót śś. Jana Chrzciciela i Jana Ewangelisty; 1280-1330). Livonijā biežo karu dēl cisterciešu klosterus mūku-brunininieki izmantoja aizsardzībai un patvērumam. 